\author{
RADOSŁAW MĘDRZYCKI \\ ORCID: 0000-0002-9407-4881 \\ Uniwersytet Kardynała Stefana Wyszyńskiego w Warszawie \\ r.medrzycki@uksw.edu.pl
}

\title{
Fundacje prawa publicznego w świetle dorobku naukowego Tadeusza Bigi
}

\begin{abstract}
Abstrakt: Celem artykułu jest charakterystyka pojęcia fundacji prawa publicznego na tle refleksji Tadeusza Bigi poświęconej związkom publicznoprawnym. Należy podkreślić ogromne znaczenie dorobku Profesora dla obecnej doktryny prawa administracyjnego. Rozważania podjęte w artykule są zobrazowane przykładami współczesnych fundacji prawa publicznego. Treść artykułu dzieli się na trzy rozdziały oraz wstęp i zakończenie z wnioskami. W badaniach użyto metody teoretycznoprawnej oraz dogmatycznoprawnej. Badania wykazały, iż istnieje teoretyczna możliwość zaliczenia fundacji prawa publicznego do kategorii związków publicznoprawnych, chociaż taka kategoryzacja napotyka na trudności związane z rzeczowym substratem fundacji.
\end{abstract}

Słowa kluczowe: fundacja, fundacja prawa publicznego, Tadeusz Bigo, związek publiczno-prawny.

\section{Uwagi wstępne}

Jednym z kluczowych opracowań w dorobku naukowym Tadeusza Bigi jest wydana w 1928 roku w Warszawie monografia pod tytułem Zwiazki publiczno-prawne w świetle ustawodawstwa polskiego. Praca ta stanowiła podstawę do habilitowania autora jako docenta ${ }^{1}$. W swojej ocenie referent komisji rzeczowej, Zbigniew Pazdro, napisał:

${ }^{1}$ Na proces habilitacyjny składały się w kolejności: podanie Habilitanta (19 stycznia 1928); referowanie podania na Radzie Wydziałowej Wydziału Prawa i Umiejętności Politycznych Uniwersytetu Jana Kazimierza we Lwowie (dalej: Rada Wydziałowa) przez dziekana prof. K. Stefanko i wybór komisji osobistej (K. Stefanko, S. Starzyński, L. Ehrlich) i komisji rzeczowej (Z. Pazdro referent, S. Starzyński - koreferent) (7 marca 1928); opinia Rady Wydziałowej (4 czerwca 1928), ocena rozprawy habilitacyjnej przez recenzentów Z. Pazdro (5 czerwca 1928) i S. Starzyńskiego 
Studium dra Bigi stanowi w zakresie polskiej literatury prawa administracyjnego istotny postęp. Nie mamy dotychczas żadnej pracy o związkach prawno-publicznych w systemie administracji polskiej, znajdują się tylko oderwane i przygodne wzmianki z tego zakresu. Studjum dra Bigi wypełnia zatem istniejącą lukę i daje podstawy do opanowania zagadnień tych związków w przyszłości [...]. W każdym razie droga jest utorowaną i nikt, kto w przyszłości zajmie się tym problemem, nie będzie mógł pominąć pracy dra Bigi i wyników, do których doszedł. W tem leży trwała wartość jego studium²

Wiele lat później Jan Boć stwierdził:

Praca habilitacyjna o związkach publicznoprawnych w świetle ustawodawstwa polskiego jest dziś z powodzeniem cytowana i przepisywana. Okoliczność ta daje wiele do myślenia. Okazuje się, że podstawowe ustalenia w sprawach stosunków społeczno-prawnych mogą być — mimo pędu cywilizacyjnego — równie trwałe, jak składowe elementy materii fizycznej ${ }^{3}$.

Należy w pełni podzielić powyższe poglądy. Jednocześnie warto nadmienić, że dzieło Tadeusza Bigi zostało wydane jako reprint w I Serii Klasyki Samorządowej przez wydawnictwo Przemiany w 1990 roku i zaliczone przez redaktorów (Michała Kuleszę i Aleksandrę Wiktorowską) do kanonu literatury samorządowej, którą — jak wynika z kontekstu historycznego — należało znać w procesie restytucji samorządu terytorialnego.

Argumenty o trwałości i uniwersalności myśli naukowej Tadeusza Bigi znajdują potwierdzenie w licznych odwołaniach do jego dzieła we współczesnej literaturze samorządowej ${ }^{4}$. Warto jednak zwrócić uwagę, że ponadczasowość tego charakterystycznego dla dorobku Tadeusza Bigi dzieła zasadza się również na możliwości odniesienia wyrażonej tam koncepcji naukowej szerzej, niż tylko do samorządu terytorialnego. We wskazanej pracy autor pisał: „Fundacja i korporacja to nie są dwie różnorodne instytucje, które by łączyła sztucznie nazwa sama, lecz to są dwie odmiany jednej instytucji [osoby prawnej], które różnią się między sobą tylko strukturą".

(10 czerwca 1928 - przystąpienie w całości), dyskusja habilitacyjnej (12 czerwca 1928 - uznanie rozprawy jednomyślnie za odpowiadającą wymogom ustawowym i dopuszczenie jej do dalszych czynności), wykład habilitacyjny pod tytułem Prawomocność aktów administracyjnych $w$ prawie polskim (14 czerwca 1928, godz. 12.15-13.00), głosowanie Rady Wydziałowej (15 czerwca 1928), akceptacja Senatu Akademickiego, akceptacja ministra wyznań religijnych i oświecenia publicznego (pismo z 16 sierpnia 1928) - rekonstrukcja procesu za: P.M. Żukowski, Tadeusz Antoni Bigo (1894-1975). Droga na katedrę uniwersytecka we Wrockawiu, „Folia Iuridica Universitatis Wratislaviensis" 2015, nr 4, s. 19-21.

2 Za: ibidem, s. 45.

3 J. Boć, Tadeusz Bigo, [w:] Pamięci zmartych profesorów i docentów Wydziału Prawa, Administracji i Ekonomii Uniwersytetu Wrocławskiego 1945-2000, red. L. Lehmann, M. Maciejewski, Wrocław 2010, s. 23.

4 Zob. np. I. Lipowicz, Samorzad terytorialny XXI wieku, Warszawa 2019; J. Korczak, Pojęcie władztwa statutowego, [w:] Układ administracji publicznej, red. J. Korczak, Warszawa 2020; idem, Konstytucyjne podstawy samodzielności jednostek samorzadu terytorialnego, [w:] Równość w prawie administracyjnym, red. J. Korczak, P. Lisowski, Warszawa 2018; D. Dąbek, Dopuszczalny zakres samodzielności prawotwórczej a istota samorzadu terytorialnego - postulaty, [w:] Unitarny charakter państwa a samorząd terytorialny, red. K. Małysa-Sulińska, M. Stec, Warszawa 2019; M. Mączyński, Zadania samorzadu terytorialnego w dziedzinie bezpieczeństwa publicznego, [w:] Charakter i konstrukcja zadań samorządu terytorialnego, red. S. Płażek, M. Stec, Warszawa 2017.

Prawo 333, 2021

(C) for this edition by CNS 
Biorąc pod uwagę dużą otwartość koncepcji autora, interesująca będzie próba współczesnej charakterystyki fundacji prawa publicznego na tle refleksji Tadeusza Bigi oraz współczesnej wiedzy naukowej o związkach publicznoprawnych. Same fundacje prawa publicznego, w odróżnieniu od fundacji prawa prywatnego, stanowią również niezwykle ciekawy i relatywnie rzadki przedmiot analizy $\mathrm{w}$ doktrynie prawa administracyjnego. W związku z bardzo ograniczoną ich liczbą w obecnym porządku prawnym (podobnie zresztą w Polsce przedwojennej) warto szerzej odnieść się do określonych przykładów istniejących historycznie i współcześnie fundacji.

\section{Pojęcie i cechy fundacji prawa publicznego}

Tematyka fundacji zarówno w ogólności, jak również w odniesieniu do fundacji prawa publicznego, łączona bywa w literaturze z pojęciem decentralizacji. Chociaż obecnie termin ten wiąże się silnie z dyskursem o samorządzie terytorialnym, nie można zapominać, że przejawem decentralizacji jest istnienie również wielu innych podmiotów prawa. Dostrzegał to już Tadeusz Bigo ${ }^{5}$. W tym kontekście fundacje in genere jawią się jako jeden $\mathrm{z}$ nich ${ }^{6}$. Decentralizacji nie można ograniczać wyłącznie do aspektu terytorialnego, chodzi bowiem także o przekazywanie zadań państwowych podmiotom pozapaństwowym (niepublicznym), co z kolei każe widzieć to zagadnienie w kontekście pomocniczości ${ }^{7}$. Odrębność od innych podmiotów przejawiająca się posiadaniem osobowości prawnej i własnym statutem oraz - przede wszystkim — scedowaniem na tym odrębnym podmiocie w drodze ustawy określonych zadań administracji publicznej, a także poddanie go nadzorowi, w pełni uzasadniają tezę o zaliczeniu fundacji prawa publicznego do form decentralizacji administracji publicznej.

Zagwarantowana konstytucyjnie wolność tworzenia i działania fundacji, wraz ze związkami zawodowymi organizacjami społeczno-zawodowymi rolników, stowarzyszeniami, ruchami obywatelskimi i innymi dobrowolnymi zrzeszeniami, stanowi realizację zasady pluralizmu społecznego i społeczeństwa obywatelskiego (art. 12 Konstytucji $^{8}$ ) niezbędną dla urzeczywistniania dobra wspólnego ${ }^{9}$. Jest

5 T. Bigo, Związi publiczno-prawne w świetle ustawodawstwa Polskiego, Warszawa 1928 (reprint 1990), s. 181.

6 S. Fundowicz, Decentralizacja administracji publicznej w Polsce, Lublin 2005, s. 271-281.

7 W. Sokolewicz, Artykut 12, [w:] Konstytucja Rzeczpospolitej Polskiej. Komentarz, t. 5, red. L. Garlicki, Warszawa 2007, s. 3.

${ }^{8}$ Konstytucja Rzeczpospolitej Polskiej z dnia 2 kwietnia 1997 roku (Dz.U. z 1997 r. Nr 78, poz. 483 z późn. zm.).

9 Postrzeganego w aspekcie klasycznym a nie etatystycznym; szerzej zob. M. Piechowiak, Prawne a pozaprawne pojęcie dobra wspólnego, [w:] Dobro wspólne. Teoria i praktyka, red. W. Arndt, Warszawa 2013. 
to jednocześnie ważne dopełnienie gwarantowanego art. 11 Konstytucji pluralizmu politycznego.

Zgodnie z przedwojenną definicją Wilhelma Edmunda Rappègo i doktryną współczesną, fundacja prawa publicznego jest podmiotem posiadającym osobowość prawną, o celowym charakterze wyrażającym się w powołaniu do realizacji konkretnych zadań administracji publicznej powstałą poprzez akt publicznoprawny i opartą o element majątkowy ${ }^{10}$. W tym kontekście trzeba jednak powiedzieć o wyraźnym dwupodziale fundacji na fundacje prawa prywatnego i fundacje prawa publicznego.

Wśród elementów różnicujących te dwa typy fundacji wymienić należy:

a) ustawowe źródło prawa fundacji,

b) sposób ustanowienia fundacji,

c) pojęcie interesu z jakim związane są cele fundacji, chociaż ostatni z tych punktów rodzi wątpliwości.

W przypadku źródła prawa będącego podstawą funkcjonowania fundacji prawa prywatnego jest ustawa $\mathrm{z}$ dnia 6 kwietnia 1984 roku o fundacjach ${ }^{11}$ (nie wyłączając oczywiście każdorazowego statutu fundacji), natomiast w przypadku fundacji prawa publicznego konkretna ustawa lub upoważnienie ustawowe inne niż ustawa o fundacjach.

Natomiast podstawami obecnie funkcjonujących w obrocie prawnym fundacji prawa publicznego są: ustawa z dnia 5 stycznia 1995 roku o fundacji — Zakład Narodowy imienia Ossolińskich ${ }^{12}$, ustawa z dnia 20 lutego 1997 roku o fundacji - Centrum Badania Opinii Społecznej ${ }^{13}$, ustawa z dnia 18 września 2001 roku o fundacji - Zakłady Kórnickie ${ }^{14}$, ustawa z dnia 17 stycznia 2019 roku o Fundacji Platforma Przemysłu Przyszłości ${ }^{15}$ oraz statuty tych podmiotów.

W literaturze istnieją również głosy zaliczające do fundacji prawa publicznego fundacje utworzone w drodze umowy międzynarodowej (na przykład Fundacja „Polsko-Niemieckie Pojednanie”), albo przez ministrów (Fundacja na Rzecz Nauki Polskiej)"16. Można mieć jednak wątpliwość, czy fundacje te, działające

10 E. Reppé, Encyklopedia nauk politycznych, t. 2, Warszawa 1937, s. 258 n.; E. Ochendowski, Fundacje prawa publicznego - nowy podmiot administracji, [w:] Gospodarka. Administracja. Samorzą, red. H. Olszewski, B. Popowska, Poznań 1997, s. 362: S. Fundowicz, Fundacje publiczne, [w:] Prawo administracyjne ustrojowe. Podmioty administracji publicznej, red. J. Stelmasiak, J. Szreniawski, Bydgoszcz-Lublin 2002, s. 194; S. Fundowicz, Decentralizacja ..., s. 271; M. Okoń, Fundacje prawa prywatnego a fundacje prawa publicznego. Zagadnienie nadzoru nad ich działalnościa, „Administracja. Teoria - Dydaktyka — Praktyka” 2011, nr 3, s. 162-163.

11 Dz.U. z 2020 r. poz. 2167, dalej u.f.

12 Dz.U. z 2017 r. poz. 1881.

13 Dz.U. z 1997 r. Nr 30, poz. 163.

14 Dz.U. z 2020 r. poz. 1705.

15 Dz.U. z 2019 r. poz. 229.

16 A. Matan, [w:] G. Łaszczyca, C. Martysz, A. Matan, Kodeks postępowania administracyjnego. Komentarz, t. 2. Komentarz do art. 104-269, Warszawa 2010, art. 224. 
zasadniczo na podstawie ustawy o fundacjach ${ }^{17}$, można nazywać fundacjami prawa publicznego. Jeżeli przenieść punkt ciężkości na ich działalność, która dotyczy realizacji zadań publicznych, nazwa ta jest uzasadniona. Jednak jeżeli zaakcentuje się zarówno formalnoprawny profil działalności, jak i podstawy działalności, przy przyjęciu, że ustawa prawo o fundacjach ma jednak charakter prywatnoprawny, wypada zaliczyć takie podmioty do nieco innej grupy — fundacji publicznych.

Jak wskazuje Małgorzata Stahl:

Zadania fundacji utworzonych ustawami mają charakter szczególnie ważnych zadań publicznych, mieszczących się w zadaniach ogólnie określonych w ustawie o fundacjach (stanowiących realizację celów społecznie lub gospodarczo użytecznych, zgodnych z podstawowymi interesami Rzeczypospolitej Polskiej, w szczególności takich, jak ochrona zdrowia, rozwój gospodarki i nauki, oświata i wychowanie, kultura i sztuka, opieka i pomoc społeczna, ochrona środowiska i zabytków). Wskazane przymioty - utworzenie w drodze ustawy, wykonywanie określonych ustawą zadań publicznych, poddanie nadzorowi organów państwa — statuują ich publicznoprawny charakter ${ }^{18}$.

$\mathrm{Na}$ gruncie dotychczasowych rozważań należy się jednak zastanowić nad adekwatnością sformułowania „fundacja prawa prywatnego" w stosunku do źródła i charakteru norm wynikających z ustawy o fundacjach. Wydaje się, że nie jest przesądzone jednoznacznie, czy owo źródło ustawowe zaliczyć do prawa cywilnego, czy administracyjnego; wszak zainteresowanie fundacjami pojawia się u przedstawicieli tych dwóch odmiennych przecież dziedzin prawnych ${ }^{19}$. Zwróciła na to uwagę również Jolanta Blicharz, przywołując poglądy Reppégo, który pisał, iż prawo fundacyjne poza kwestią osobowości prawnej jest częścią prawa administracyjnego, w samej zaś instytucji fundacji łączą się cechy struktury przynależnej prawu cywilnemu i prawu administracyjnemu ${ }^{20}$.

Również obecnie zagadnienia prawa fundacyjnego czasami są elementem podręczników materialnego prawa administracyjnego lub też wydzielonych rozdziałów prawa materialnego w podręcznikach prawa administracyjnego ${ }^{21}$. Jeżeli

17 Zob. https://www.fnp.org.pl/assets/Statut-FNP_24_10_2018.pdf; https://www.fpnp.pl/Statut.html (dostęp: 15.04.2021).

18 M. Stahl, Inne podmioty administrujace, [w:] System Prawa Administracyjnego, t. 6. Podmioty administrujące, red. R. Hauser, Z. Niewiadomski, A. Wróbel, Warszawa 2011, s. 519.

19 A. Kidyba, Fundacje i stowarzyszenia. Zagadnienia podstawowe, Warszawa 1995; J. Blicharz, Fundacje. Wybrane zagadnienia, Wrocław 2016; J. Blicharz, Ustawa o fundacjach. Komentarz, Wrocław 2002; J. Blicharz, Przykłady fundacji, [w:] Prawo administracyjne, red. J. Boć, Wroclaw 2001.

20 W.E. Reppé, Fundacje, Warszawa 1937, s. 20 oraz idem, Fundacje, [w:] Encyklopedia Podręczna Prawa Publicznego, t. 1, z. 3, Warszawa 1926, s. 151, cyt. za: J. Blicharz, Fundacje, [w:] Tadeusz Bigo o administracji i prawie administracyjnym - refleksje wrocławskiej szkoły administratywistycznej, red. T. Kocowski, P. Lisowski, M. Paplicki, Wrocław 2020, s. 209.

${ }^{21}$ K.W. Kumaniecki, B. Wasiutyński, J. Panejko, Polskie prawo administracyjne $w$ zarysie, Kraków 1929; K.W. Kumaniecki, J.S. Langrod, S. Wachholz, Zarys ustroju, postępowania i prawa administracyjnego w Polsce, Kraków-Warszawa 1939, s. 155 n.; Prawo administracyjne. Część ogólna, ustrojowe prawo administracyjne, wybrane zagadnienia materialnego prawa administracyjnego, red. M. Zdyb, J. Stelmasiak, Warszawa 2020, s. 709 n. Skutkiem zniesienia fundacji na 
zaliczyć prawo fundacyjne do prawa administracyjnego, wyłuszcza się umowność stosowanego obecnie nazewnictwa, znikają bowiem formalne podstawy do nazywania fundacji funkcjonujących, w oparciu o ustawę o fundacjach - fundacjami prawa prywatnego.

Sposób ustanowienia fundacji prawa prywatnego (czynność założycielska) może się wiązać z aktem prywatnoprawnym, to jest aktem fundacyjnym będącym oświadczeniem woli fundatora albo wyrażeniem jego woli w testamencie. Ustanowienie fundacji prawa publicznego (akt założycielski) ma postać aktu publicznoprawnego albo aktu administracyjnego opartego oczywiście o przepisy aktu normatywnego ${ }^{22}$.

Określone kłopoty wywołuje przesłanka interesu. Przyjęto zasadę, że fundacja prawa prywatnego działa $\mathrm{w}$ interesie prywatnym, prawa publicznego zaś — w interesie publicznym. Nie sposób nie zgodzić się z takim postrzeganiem fundacji prawa publicznego. Niemniej o wiele większy kłopot sprawia jednoznaczna klasyfikacja realizacji wyłącznie interesu prywatnego w związku z możliwością działania fundacji prawa prywatnego.

Po pierwsze, fundacje prawa prywatnego mogą realizować zadania publiczne na podstawie zlecenia. Jako ważny przykład regulacji umożliwiającej działalność w sferze publicznej wymienić należy przepis art. 25 ust. 1 ustawy z dnia 12 marca 2004 roku o pomocy społecznej stanowiący, że

organy administracji rządowej i samorządowej [...], mogą zlecać realizację zadania z zakresu pomocy społecznej, udzielając dotacji na finansowanie lub dofinansowanie realizacji zleconego zadania organizacjom pozarządowym, o których mowa w art. 3 ust. 2 ustawy z dnia 24 kwietnia 2003 roku o działalności pożytku publicznego i o wolontariacie oraz podmiotom wymienionym $\mathrm{w}$ art. 3 ust. 2 tej ustawy, prowadzącym działalność w zakresie pomocy społecznej ${ }^{23}$.

Zgodnie z przepisem, do którego wiedzie odesłanie, za organizację pozarządową uznać również należy fundację z wyłączeniem fundacji utworzonych przez partie polityczne i europejskie fundacje polityczne.

Po drugie, fundacje prawa prywatnego mogą być tworzone przez podmioty zaliczane do administracji państwowej. Jakkolwiek podstawa tworzenia ma charakter prywatnoprawny, to jednak cel fundacji związany jest silnie z realizacją interesu publicznego. W tym miejscu należy poczynić ważną uwagę. Na mocy art. 45 ustawy o finansach publicznych ze środków publicznych nie można tworzyć fundacji na podstawie ustawy o fundacjach. Tak ogólna regulacja może wywoływać konfuzję, zdaje się bowiem przeczyć tezie o możliwości tworzenia fundacji prawa prywatnego przez podmioty publiczne. Wynikają z niej jednak dwa inne

mocy dekretu z dnia 24 kwietnia1952 roku o zniesieniu fundacji (Dz.U. z 1952 r. Nr 25, poz. 172 ze zm.) było przerwanie refleksji naukowej nad ta tematyką przez przedstawicieli prawa administracyjnego w Polsce na ponad 30 lat.

22 S. Fundowicz, Fundacje..., s. 197.

23 Dz.U. z 2020 r. poz. 1876 z późn. zm. 
wnioski. Pierwszy, choć nie najważniejszy, to ten, że ustawodawca może utworzyć fundację na mocy ustawy szczególnej ${ }^{24}$, drugi - prawo zaś może zezwalać na utworzenie fundacji prawa prywatnego. Przykładowo tworzenie fundacji przysługuje wprost z mocy ustawy jednostkom samorządu powiatowego i województwa - samorządy te nie mogą przeznaczyć środków publicznych na takie fundacje. Jednostki sektora finansów publicznych mogą jednak przeznaczyć na utworzenie fundacji rzeczy ruchome i nieruchomości ${ }^{25}$.

Po trzecie należy wziąć pod uwagę wyrażane przez Tadeusza Bigę zastrzeżenie, że nie można uzasadniać wyróżnienia fundacji prawa publicznego na podstawie tego, iż prowadzą one działalność służącą celowi ogólnie użytecznemu i są nadzorowane przez państwo ${ }^{26}$. Taka logika działania i organizacji wpisana jest również w fundacje prawa prywatnego. Poglądy te zachowują zatem aktualność również dzisiaj, gdy weźmie się pod uwagę przepis art. 1 u.f. stanowiący, że „fundacja może być ustanowiona dla realizacji zgodnych z podstawowymi interesami Rzeczypospolitej Polskiej celów społecznie lub gospodarczo użytecznych". Naturalne jest również, że fundacje prawa prywatne podlegają nadzorowi państwa (art. 12 u.f.p., a w zakresie środków nadzoru art. 13 i 14 u.f.p.).

\section{Zrzeszenia i korporacje}

Kolejne zagadnienie związane jest z możliwością zaliczenia fundacji prawa publicznego do podmiotów objętych gwarancjami wolności zrzeszania się z art.12 Konstytucji. Już samo umiejscowienie w tym przepisie fundacji obok zrzeszeń budziło poważne zastrzeżenia. Zastrzeżenie to generuje fakt, że fundacje prawa publicznego, tak samo zresztą jak fundacje prawa prywatnego, nie są formą zrzeszeń, gdyż nie opierają się na elemencie osobowym, ale kapitałowym. Stąd powstaje problem, czy fundacje w dwóch typach — tak jak jest to charakterystyczne dla zrzeszenia - służą realizacji interesów obywateli i wyrażania ich opinii? ${ }^{27}$

Przyjrzyjmy się na wstępie poglądom Tadeusza Bigi na temat różnicy między zrzeszeniami (korporacjami) a fundacjami. Autor tak pisał o tej kwestii w 1928 roku:

jeśli mówi się o istotnej różnicy między korporacją a fundacją, to odnosi się to nie do osób prawnych, lecz do faktów socjalnych. Słusznie też zauważa Herrnritt, że to co się dotychczas nazywało substratem rzeczowym, jest właściwie tylko funduszem zakładowym (Anstaltsfond) i dlatego proponuje nazwę: substrat — zachować dla oznaczenia grupy osób (substrat osobowy), która jest

24 P. Przybysz, Instytucje prawa administracyjnego, Warszawa 2020. Zob. przywołane wyżej przykłady fundacji prawa publicznego.

${ }^{25}$ M. Ofiarska, [w:] Ustawa o finansach publicznych. Komentarz, red. Z. Ofiarski, Warszawa 2020, art. 45.

26 T. Bigo, Związki..., s. 180.

27 W. Sokolewicz, Artykut 12..., s. 6. 
istotnym momentem tak dla konstrukcji, jak i korporacji. Między korporacją a fundacją (zakładem) zachodzą różnice strukturalne; pochodzą one z różnego rodzaju ustosunkowania obydwóch elementów organizacyjnych: aktu konstytucyjnego i organów. W korporacji członkowie grupy są twórcami aktu konstytucyjnego (założycielskiego), są założycielami, oni stanowią normy organizacyjne, oraz ustanawiają organa; w fundacji (zakładzie) akt konstytucyjny pochodzi od osoby trzeciej, nie należącej do składu grupy społecznej, której działania są przedmiotem personifikacji, czyli od tak zwanego fundatora; akt konstytucyjny (fundacyjny) zawiera normy organizacyjne, które określają sposób tworzenia organów. Substratem osobowym fundacji (zakładu) jest grupa osób zarządzających fundacją: zarząd (razem z kuratorem) ${ }^{28}$.

Fundację od korporacji odróżnia zatem to, że tą pierwszą nie kierują jej członkowie. Inną ważną różnicą jest trwałość celów obu podmiotów chodzi szczególnie o możliwość zmiennego celu korporacji i trwałość celu fundacji ${ }^{29}$.

Czy można zatem fundacje prawa publicznego zaliczyć do podmiotów społeczeństwa obywatelskiego i objąć je ochroną wynikającą z art. 12 Konstytucji? Przede wszystkim — jak wskazywał Tadeusz Bigo — dostrzec należy różnice w samej woli konstytuującej dany podmiot. W przypadku zrzeszeń są to określone osoby chcące wyrazić swoje interesy, dążenia, zainteresowania. W fundacji wola realizacji określonych interesów wyraża się w akcie fundatora i celu, i określeniu sposobów jego osiągania, jakie ostatecznie wskazuje się w statucie fundacji. Niemniej podnieść należy, że fundacje prawa publicznego tworzone są przez władze publiczne, a zatem trudno osądzić, że mogą być one zaliczone do kategorii społeczeństwa obywatelskiego. W związku z uwagami Bigi chyba można stwierdzić, że do społeczeństwa obywatelskiego bliżej fundacjom prawa prywatnego tworzonym przez podmioty niezależne od administracji.

Obecnie fundacje prawa prywatnego mogą być również tworzone przez niektóre władze publiczne ${ }^{30}$, a to oznacza, że o zaliczeniu fundacji do kategorii podmiotów społeczeństwa obywatelskiego decyduje zasadniczo zaliczenie fundatora do podmiotów stojących poza władzą publiczną. W tym kontekście widzieć chyba należy ewentualny dodatkowy podział na fundacje prawa publicznego i fundacje publiczne utworzone przez organy władzy publicznej jednak działające w oparciu o przepisy ustawy prawo o fundacjach ${ }^{31}$. Widać niejednolitość poglądów doktrynalnych w tym zakresie. Przykładami tak zwanych problematycznych fundacji są Fundacja „Polsko-Niemieckie Pojednanie” czy Fundacja na Rzecz Nauki Polskiej, a więc fundacje utworzone w drodze prywatnoprawnych oświadczeń woli określonych ministrów i kierowników urzędów centralnych w drodze aktu fundacyjnego opartego o przepisy ustawy prawo o fundacjach ${ }^{32}$. Myślę, że pewnego

28 T. Bigo, Związki publiczno-prawne..., s. 48-49.

29 S. Fundowicz, Fundacje..., s. 195-196.

${ }^{30}$ K. Szlachetko, Fundacje Samorzadowe, [w:] Podmiotowość samorzadu terytorialnego a zakres jego zadań i kompetencji, red. K. Małysa-Sulińska, M. Stec, Warszawa 2020.

31 Zob. M. Stahl, Inne..., s. 518 n.

32 Fundacji te zalicza do fundacji prawa publicznego Sławomir Fundowicz, chociaż posługuje się też w odniesieniu do nich pojęciem fundacji publicznej. Zob. idem, Fundacje publiczne..., 
zamieszania terminologicznego można uniknąć postulując wprowadzenie pojęcia fundacji prawa prywatnego sensu stricto oraz sensu largo. Fundacja prawa prywatnego sensu stricto byłaby fundacją, której źródło jak i czynność założycielska ma charakter prywatnoprawny a dodatkowo podmiot ją tworzący jest podmiotem niepublicznym (prywatnym). Fundacja prawa prywatnego sensu largo to obok wspomnianej wyżej kategorii także podmioty, dla której źródło jak i czynność założycielska ma charakter prywatnoprawny, lecz podmiot ją tworzący jest podmiotem publicznym (również samorząd terytorialny). Już sam aspekt podmiotowy przejawiający się w zaliczeniu fundatora do zbioru podmiotów administracji państwowej lub samorządowej ogranicza - moim zdaniem - tworzenie fundacji dla prywatnych celów, w myśl tezy, iż podmioty administracyjne nie mają swojego własnego interesu prawnego, lecz ich działalność służyć ma wyłącznie realizacji interesu publicznego (interesu wspólnoty samorządowej) w dążeniu do osiągnięcia dobra wspólnego. Nawet wtedy, gdy jednostka samorządu terytorialnego utworzy fundację w celach promocyjnych, to realizuje tym samym zadanie publiczne, a więc dba o interes wspólnoty samorządowej, a nie swój własny.

Fundacje prawa publicznego zaliczyć należy do tak zwanej administracji pośredniej — w literaturze można spotkać nazwę wtórne podmioty administracji publicznej ${ }^{33}$. W odróżnieniu od administracji bezpośredniej, do której zalicza się organy administracji publicznej, administrację pośrednią tworzą podmioty zdecentralizowane, którym służy odpowiedni poziom samodzielności prawnie chronionej ${ }^{34}$. Samodzielność tę widać w sferze typowego związku publicznoprawnego, jakim jest samorząd terytorialny, ale można ją dostrzec także w fakcie samodzielności działania fundacji. Fundacje prawa publicznego zachowują względną samodzielność w zakresie wyboru środków działania, lecz ich cele i organizacja są określone przez państwo. Fundacje prawa publicznego, wpisując się w struktury administracji publicznej funkcjonalnie, podmiotowo stoją zatem pomiędzy podmiotami prawa publicznego i prywatnego.

Fundacje prawa publicznego wyjątkowo występują w polskim ustroju administracji publicznej. Są one zakładane wyłącznie w celu realizacji określonego zadania publicznego lub niewielkiej grupy zadań publicznych, zwykle o szczególnej doniosłości dla kultury, nauki, pamięci historycznej Narodu Polskiego. Podstawy ich utworzenia, działalności i zakres działania, jak również kompetencji stanowią ustawy specjalne. [...] Fundacje prawa publicznego spełniają jedynie uzupełniającą rolę w zakresie wykonywania zadań publicznych. Niektóre spośród istniejących mają głębokie

s. 201-202. Inaczej traktuje je z kolei Michał Okoń stwierdzając jednoznacznie, że adekwatną nazwą do nich jest wyłącznie fundacja publiczna. M. Okoń, Fundacje..., s. 166. M. Okoń, Fundacje prawa publicznego w prawie polskim, „Kontrola Państwowa” 2012, nr 1, s. 108-109. Zob. także postanowienie NSA z 19 lutego 1999 roku, sygn. V SAB 7/99 (CBOSA) i krytyczną glosę E. Łętowska, Glosa do postanowienia NSA z 19 lutego 1999 roku, V SAB 7/99, OSP 82, nr 5.

33 R. Stasikowski, Pluralizm administracji publicznej, Warszawa 2019, s. 93 n.

34 K. Kiczka, L. Kieres, T. Kocowski, M. Szydło, Administracja gospodarcza zorganizowana w sposób swoisty, [w:] System Prawa Administracyjnego, t. 8A. Publiczne prawo gospodarcze, red. R. Hauser, Z. Niewiadomski, A. Wróbel, Warszawa 2018, s. 670. 
korzenie historyczne i wywarły przede wszystkim w przeszłości duży wpływ na rozwój, przede wszystkim kultury polskiej. Naturalnie nie jest wykluczone powoływanie i dzisiaj tego typu instytucji. Są one częścią systemu administracyjnego. Ich wyodrębnienie ze struktur scentralizowanych służy zapewnieniu im większej autonomii i uchronieniu ich działalności od bieżącego wpływu woli politycznej płynącej z systemu politycznego na struktury scentralizowane ${ }^{35}$.

Zaprezentowane uwagi skłaniają do próby odpowiedzi na pytanie, czy fundację prawa publicznego można w ogóle zaliczyć do kategorii związków publiczno-prawnych?

Należy przede wszystkim zwrócić uwagę na elementy opisu związków publiczno-prawnych, których użył w swojej pracy Tadeusz Bigo.

Opisując zastany stan normatywny autor dokonał charakterystyki wyróżnionych podmiotów za pomocą następujących kategorii: 1) sposób powstania i członkostwo, 2) stosunek do państwa, 3) środki działania (organizacja), 4) nadzór, 5) stosunek do członków. Należy oczywiście zastrzec, iż badacz, przystępując do analizy, wyraźnie stwierdził, że w swojej pracy zajął się związkami (korporacjami) publicznoprawnymi. Nie może dziwić zatem odniesienie się do kategorii stosunku do członków czy członkostwa. Ostatecznie Tadeusz Bigo konstatował, że:

a) analizowane przez niego związki publicznoprawne zajmują się różnorodną działalnością,

b) którą to działalność mogą wykonywać również związki prywatne,

c) odrębności między nimi widoczne są w: sposobie powstania i członkostwa, stosunku do państwa, środkach działania ${ }^{36}$.

Co do ostatnich cech Tadeusz Bigo stwierdził:

Przede wszystkim są to organizacje przymusowe w tem znaczeniu, że 1 - powstanie ich nie zależy od objawu woli członków albo przynajmniej nie zależy od niego w pierwszym rzędzie; 2 — przynależność do związku zależy od pewnego w ustawie określonego stanu faktycznego [...] Dalej, stosunek do państwa wykazuje znów tę odrębność, że nadzór państwa nad temi związkami nie ogranicza się do tzw. policyjnego nadzoru, ale idzie dalej; władze nadzorcze dysponują takiemi pozytywnymi środkami, jak rozwiązanie organów związku, ustanowienie zastępczych, komisarycznych zarządów, zatwierdzanie uchwał, przymusowe wykonywanie zastępcze zadań związku i t.p. W końcu środki działania tych związków wykazują uderzające różnice w stosunku do prywatnych koproracyj: akty organów związkowych mogą być wykonywane bez pośrednictwa drogi sądowej, a nawet przy użyciu przymusu administracyjnego; władza związku przekracza granice zwykłej władzy korporacyjnej; dyscyplinarnej; w pewnych wypadkach obejmuje także osoby trzecie, nie członków (związki samorządu terytorialnego, izby przem. handlowe) $)^{37}$.

Wobec trzech kryteriów, autor, chcąc wyróżnić cechy charakterystyczne dla korporacyjnego związku publicznoprawnego, zasadnie odrzucił kryterium szczególnego nadzoru państwa, gdyż, jak pokazał, cele związku nie do końca różnicują

35 R. Stasikowski, Pluralizm administracji publicznej, Warszawa 2019, s. 189-190.
36 T. Bigo, Zwiazki..., s. 76 n.
37 Ibidem, s. 76-77.

Prawo 333, 2021

(C) for this edition by CNS 
związki publiczne od prywatnych, również związki prywatne mogą działać w celach publicznych - stwierdzenie to zachowuje aktualność również obecnie ${ }^{38}$.

Ostatecznie Tadeusz Bigo doszedł do rozróżnienia związków publicznoprawnych w typie korporacji na podstawie dwóch przesłanek: specyficznych środków działania (chodzi o możliwość użycia władztwa administracyjnego) oraz przymusu tworzenia związku i przymusowego członkostwa. Proponując finalną definicję związku publicznoprawnego - w rozumieniu polskiego ustawodawstwa - Tadeusz Bigo stwierdził, że jest to związek uposażony w władztwo administracyjne i powołany do życia przez państwo względnie przy jego czynnym udziale. Przez pojęcie władztwa autor rozumiał: uprawnienie do stosowania przymusu administracyjnego i na wyłączeniu sporów spod właściwości sądów, jednocześnie nie chodzi tu o władztwo korporacyjne wobec swoich członków ${ }^{39}$. To ważne stwierdzenie, ponieważ wraz z elementem pierwszym daje asumpt do rozważenia, czy elementy te spełnione są w przypadku fundacji prawa publicznego. Można powiedzieć, że na gruncie dociekań autor wyeliminował te fragmenty opisu stanu normatywnego, które wskazywały na kategorialne przesunięcie - pozostały bowiem te elementy charakterystyki, które oderwały się od cech wyłącznie korporacyjnych. Pewnym mankamentem tego rozumowania jest natomiast to, że — jak stwierdził sam autor na wstępie badań - interpretacja cech związków publicznoprawnych w typie korporacyjnym następowała na gruncie normatywnym, nie była zaś wymysłem teoretycznym, pod który „podkładano” zastany stan normatywny.

Biorąc pod uwagę ustawowy charakter fundacji prawa publicznego, możemy bez wątpienia stwierdzić, że są one powoływane przy bezpośrednim udziale państwa. Swoją drogą, tyczy się to również fundacji publicznych - a więc tych, które opierają swoje działanie na ustawie o fundacjach, jednak zostały utworzone w drodze jakiegoś aktu organu administracyjnego.

Co do władztwa. W okresie międzywojennym do fundacji spełniających ten „wymóg” zaliczano (Reppé) fundację „Wieś Kościuszkowska” oraz fundację Zamoyskich - Zakłady Kórnickie ${ }^{40}$. Zaliczenie takie jest o tyle kontrowersyjne, ponieważ wydaje się nie znajdować podstaw ustawowych i statutowych. Analiza treści ustawy z dnia 23 marca 1929 roku o utworzeniu państwowej fundacji pod nazwą „Wieś Kościuszkowska”41 (liczy pięć artykułów) nie zawiera żadnego zlecenia funkcji fundacji czy też innych oznak możliwości stosowania władztwa. Celem fundacji była opieka i wychowanie sierot po poległych i zmarłych w związku ze służbą w obronie Państwa Polskiego. Podobnie nie wydaje się, aby przejawy władztwa normował wydany na podstawie art. 3 tej ustawy statut ${ }^{42}$,

38 P. Wilczyński, Podmioty niepubliczne w sferze administracji publicznej, „Państwo i Prawo” 2002, nr 2, s. 49-62.

39 T. Bigo, Zwiazki..., s. 84-85.

40 J. Blicharz, Fundacje..., s. 211 i cytowana tam literatura.

41 Dz.U. z 1929 r. Nr 24, poz. 248.

42 M.P. 1930 r. poz. 17, s. 1-2. 
chyba że za taki uznać kompetencje Zarządu między innymi do przyjmowania gospodarzy-opiekunów, tudzież zawieranie z nimi umów szczegółowych, przyjmowanie i zwalnianie pracowników i funkcjonarjuszów Fundacji oraz określanie ich wynagrodzenia (§ 16 pkt 6 i 9). Być może za taką kwalifikacją przemawiał $\S 6$ stanowiący:

Pod opiekę Fundacji nie mogą być przyjęte dzieci, dotknięte chorobami zakaźnemu ranami zaraźliwemi lub obrzydliwemi albo wzbudzające wstręt kalectwem (sic!), paralitycy, epileptycy, dzieci niedorozwinięte, chore umysłowo, występne, lub moralnie upośledzone. Jeżeli jedna z powyższych okoliczności, wykluczających przyjęcie, okaże się lub zajdzie już po przyjęciu, w takim razie wychowanek ma być zwolniony i oddany pod opiekę osób fizycznych i lub prawnych, obowiązanych do opieki

— chodzi o ostatnie zdanie normujące konieczność zwolnienia wychowanka.

Podobna konstatacja przynależy ustawie z dnia 30 lipca 1925 roku o Zakładach Kórnickich ${ }^{43}$. Celami tej fundacji były:

1. wspieranie i rozwijanie nowoczesnego rolnictwa poprzez upowszechnianie kultury rolniczej, oświaty, wartościowych rozwiązań agrotechnicznych oraz prowadzenie wzorcowych gospodarstw rolnych;

2. działanie na rzecz edukacji rolnej i działalności naukowo-badawczej poprzez zakładanie szkół rolniczych, wspieranie nowoczesnego kształcenia, fundowanie stypendiów, organizowanie działalności upowszechniającej racjonalne gospodarowanie zasobami rolnymi;

3. propagowanie idei pracy organicznej;

4. działanie na rzecz poprawy warunków życia i pracy mieszkańców związanych z terenami Zakładów, zamieszkałych na terenach lub w pobliżu terenów Zakładów, w tym także wspieranie inicjatyw społecznych;

5. wspieranie placówek Polskiej Akademii Nauk - Biblioteki Kórnickiej i Instytutu Dendrologii.

\section{Współcześnie funkcjonujące fundacje prawa publicznego}

Z punktu widzenia celu tego krótkiego opracowania warto przyjrzeć się istniejącym obecnie fundacjom prawa publicznego.

Celami Fundacji — Zakładu Narodowego imienia Ossolińskich — są:

1. utrzymywanie Narodowej Biblioteki Ossolineum i pomnażanie jej zbiorów, zwłaszcza w zakresie humanistyki polskiej i słowiańskiej, oraz ich opracowywanie i upowszechnianie;

43 Dz.U. z 1925 r. Nr 86, poz. 592. 
2. utrzymywanie Muzeum Książąt Lubomirskich i pomnażanie jego zbiorów w zakresie sztuki i pamiątek historycznych oraz ich opracowywanie i upowszechnianie;

3. wspieranie i prowadzenie prac naukowo-badawczych;

4. działalność wydawnicza.

Celem fundacji Centrum Badania Opinii Społecznej (CBOS) jest prowadzenie badań opinii społecznej na użytek publiczny. Zadaniami CBOS w szczególności są:

1. inspirowanie, organizowanie i prowadzenie prac dotyczących badania opinii społecznej;

2. gromadzenie, opracowywanie i udostępnianie danych z badań opinii społecznej;

3. upowszechnianie w społeczeństwie wiedzy o stanie i tendencjach zmian opinii społecznej;

4. przekazywanie wyników badań organom państwowym, instytucjom publicznym i - za pośrednictwem środków masowego przekazu — społeczeństwu;

5. prowadzenie działalności wydawniczej i szkoleniowej związanej z realizacją powyższych zadań (art. 4).

Analiza ustawy ukazuje brak form władczych pozostających w kompetencji organów fundacji w sferze zewnętrznej.

W przypadku Fundacji Zakłady Kórnickie celami są:

1. wspieranie i rozwijanie nowoczesnego rolnictwa poprzez upowszechnianie kultury rolniczej, oświaty, wartościowych rozwiązań agrotechnicznych oraz prowadzenie wzorcowych gospodarstw rolnych;

2. działanie na rzecz edukacji rolnej i działalności naukowo-badawczej poprzez zakładanie szkół rolniczych, wspieranie nowoczesnego kształcenia, fundowanie stypendiów, organizowanie działalności upowszechniającej racjonalne gospodarowanie zasobami rolnymi;

3. propagowanie idei pracy organicznej;

4. działanie na rzecz poprawy warunków życia i pracy mieszkańców związanych z terenami Zakładów, zamieszkałych na terenach lub w pobliżu terenów Zakładów, w tym także wspieranie inicjatyw społecznych;

5. wspieranie placówek Polskiej Akademii Nauk — Biblioteki Kórnickiej i Instytutu Dendrologii (art. 5).

Dla realizacji celów Fundacji wyposażono ją w majątek Skarbu Państwa (art. 6 ust. 1). Analiza ustawy wskazuje brak przeniesienia funkcji administracyjnych na tę fundację.

Najpóźniej powstałą w drodze ustawy fundacją jest Fundacja Platforma Przemysłu Przyszłości. Jej celem jest działanie na rzecz wzrostu konkurencyjności przedsiębiorców poprzez wspieranie ich transformacji cyfrowej w zakresie procesów, produktów i modeli biznesowych, wykorzystujących najnowsze osiągnięcia z dziedziny automatyzacji, sztucznej inteligencji, technologii teleinforma- 
tycznych oraz komunikacji pomiędzy maszynami oraz człowiekiem a maszynami z uwzględnieniem odpowiedniego poziomu bezpieczeństwa tych rozwiązań. Fundacja ta może udzielać bezpłatnego lub odpłatnego wsparcia przedsiębiorcom, jednak — zgodnie z art. 24 ust. 6 ustawy — wybór lub odmowa przyznania wsparcia nie są czynnościami władczymi, gdyż decyduje kolejność zgłoszeń limitowana pulą wsparcia określoną w informacji o naborze zgłoszeń.

\section{Podsumowanie i wnioski}

Tematyka fundacji prawa publicznego nie znajduje się w głównym nurcie rozważań prawa administracyjnego ${ }^{44}$. Być może na stan ten wpływa fakt, że fundacje te od zawsze funkcjonowały niejako w cieniu głównego nurtu analiz — fundacji prawa prywatnego, które działają w oparciu o ustawę prawo o fundacjach. Bez wątpienia praca Tadeusza Bigi z 1928 roku, chociaż o samych fundacjach traktuje niezbyt szeroko, to jednak przynosi dla doktryny również współczesnego prawa administracyjnego interesujące wnioski. Fakt niewielkiego zainteresowania fundacjami być może wywołany był również stosunkowo małą liczbą fundacji prawa publicznego funkcjonujących w prawie polskim, jak i zasadniczymi zmianami, które nastąpiły w tym względzie w okresie PRL. Łatwości zakreślenia obszaru badawczego nie sprzyjał i nie sprzyja obecnie brak zgodności poglądów co do podmiotów, które mogą zostać zaliczone do fundacji prawa publicznego. I chociaż teza Tadeusza Bigi: „Kontrowersja panuje co do kwestii, czy dopuszczalną jest rzeczą mówić na terenie prawa administracyjnego - o fundacji: nie ma wcale zgody co do tzw. fundacji publicznej, ani co do jej egzystencji, jako instytucji prawnej, ani co do jej istoty" — wydaje się współcześnie już raczej nieaktualna, to bez wątpienia aktualne pozostało ogólne przesłanie co do braku zgody w wielu kwestiach związanych z fundacjami prawa publicznego ${ }^{45}$. W tym względzie pewnym rozwiązaniem może być posługiwanie się pojęciem fundacji publicznych, oznaczających fundacje powołane przez władze publiczne do realizacji zadań publicznych, lecz działających w oparciu o ustawę prawo o fundacjach. $Z$ drugiej strony, fundacje te można określać też jako fundacje prawa prywatnego sensu largo. Bez wątpienia złożoność materii i możliwość położenia akcentów na różne cechy charakteryzujące fundacje w prawie polskim wymaga jeszcze pogłębionych analiz doktrynalnych. To płynące również z monografii Tadeusza Bigi przesłanie zachowuje wciąż aktualność.

44 Wniosek taki można odnieść również do fundacji prawa prywatnego, co może dziwić, biorąc pod uwagę ich znaczną liczbę w obrocie prawnym.

45 T. Bigo, Zwiazki..., s. 179. 
Podobnie ma się rzecz w przypadku możliwości zaliczenia fundacji prawa publicznego - rozumianej $\mathrm{w}$ artykule jako fundacja utworzona w drodze odrębnej ustawy, dla której sama ustawa stanowi podstawowe źródło norm (obok statutu) — do kategorii związków publicznoprawnych. Kłopot z zaliczeniem fundacji do takiego związku wynika przede wszystkim z faktu, że tak zrzeszenia, jak i fundacje są odrębnymi osobami prawnymi, które różni sposób organizacji. Współcześnie doktryna jest zgodna co do tego, że podstawę istnienia fundacji stanowi majątek, a zrzeszenia — członkowie. Nie oznacza to oczywiście, że fundacja jako twór konwencjonalny nie potrzebuje do funkcjonowania w obrocie prawnym członków realizujących funkcje organów. Organy takie i członkowie są zresztą niezbędni także do funkcjonowania zrzeszeń.

Elementem spajającym pojęcie związku publicznoprawnego jest jednak według Tadeusza Bigi a) władztwo administracyjne, z którego korzysta zrzeszenie, oraz b) jego powołanie przez państwo. Trzeba jednak podkreślić, że rozumowanie autora uzależnione było od cech, jakie prawo nadawało korporacjom publicznoprawnym w okresie międzywojennym. Nie można mieć jednak wątpliwości, że w przypadku fundacji prawa publicznego druga z przesłanek jest w pełni zrealizowana. Wątpliwości można mieć jednak w stosunku do władztwa administracyjnego, które - jak wynika z analizy obecnie (ale i w przyszłości) istniejących podstaw prawnych funkcjonowania fundacji - nie jest obecne w ich charakterystyce.

Przeciwnicy zaliczenia fundacji prawa publicznego do związków publicznoprawnych mogą wskazywać również, że oparte są one na substracie materialnym, a nie osobowym. Niemniej należy zwrócić uwagę, że szerszy wywód o fundacjach publicznych zamieścił Tadeusz Bigo w rozdziale zatytułowanym Stanowisko związków publiczno-prawnych w systemach decentralistycznych, co wydaje się potwierdzać teoretyczną możliwość uznania fundacji prawa publicznego za związki publicznoprawne.

\section{Bibliografia}

Bigo T., Zwiąki publiczno-prawne w świetle ustawodawstwa Polskiego, Warszawa 1928 (reprint Warszawa 1990).

Blicharz J., Fundacje, [w:] Tadeusz Bigo o administracji i prawie administracyjnym - refleksje wrocławskiej szkoty administratywistycznej, red. T. Kocowski, P. Lisowski, M. Paplicki, Wrocław 2020.

Blicharz J., Fundacje. Wybrane zagadnienia, Wrocław 2016.

Blicharz J., Przyklady fundacji, [w:] Prawo administracyjne, red. J. Boć, Wrocław 2001.

Blicharz J., Ustawa o fundacjach. Komentarz, Wrocław 2002.

Boć J., Tadeusz Bigo, [w:] Pamięci zmartych profesorów i docentów Wydzialu Prawa, Administracji i Ekonomii Uniwersytetu Wrocławskiego 1945-2000, red. L. Lehmann, M. Maciejewski, Wrocław 2010.

Fundowicz S., Decentralizacja administracji publicznej w Polsce, Lublin 2005. 
Dąbek D., Dopuszczalny zakres samodzielności prawotwórczej a istota samorządu terytorialnego postulaty, [w:] Unitarny charakter państwa a samorząd terytorialny, red. K. Małysa-Sulińska, M. Stec, Warszawa 2019.

Fundowicz S., Fundacje publiczne, [w:] Prawo administracyjne ustrojowe. Podmioty administracji publicznej, red. J. Stelmasiak, J. Szreniawski, Bydgoszcz-Lublin 2002.

Kiczka K., Kieres L., Kocowski T., Szydło M., Administracja gospodarcza zorganizowana w sposób swoisty, [w:] System Prawa Administracyjnego, t. 8A. Publiczne prawo gospodarcze, red. red. R. Hauser, Z. Niewiadomski, A. Wróbel, Warszawa 2018.

Kidyba A., Fundacje i stowarzyszenia. Zagadnienia podstawowe, Warszawa 1995.

Korczak J., Konstytucyjne podstawy samodzielności jednostek samorządu terytorialnego, [w:] Równość w prawie administracyjnym, red. J. Korczak, P. Lisowski, Warszawa 2018.

Korczak J., Pojęcie władztwa statutowego, [w:] Układ administracji publicznej, red. J. Korczak, Warszawa 2020.

Kumaniecki K.W., Wasiutyński B., Panejko J., Polskie prawo administracyjne w zarysie, Kraków 1929.

Kumaniecki K.W., Langrod J.S., Wachholz S., Zarys ustroju, postępowania i prawa administracyjnego w Polsce, Kraków-Warszawa 1939.

Lipowicz I., Samorzad terytorialny XXI wieku, Warszawa 2019.

Matan A., [w:] Kodeks postępowania administracyjnego. Komentarz, t. 2. Komentarz do art. 104269, red. G. Łaszczyca, C. Martysz, A. Matan, Warszawa 2010.

Mączyński M., Zadania samorządu terytorialnego w dziedzinie bezpieczeństwa publicznego, [w:] Charakter i konstrukcja zadań samorządu terytorialnego, red. S. Płażek, M. Stec, Warszawa 2017.

Ochendowski E., Fundacje prawa publicznego - nowy podmiot administracji, [w:] Gospodarka. Administracja. Samorzad, red. H. Olszewski, B. Popowska, Poznań 1997.

Ofiarska M., Artykut 45, [w:] Ustawa o finansach publicznych. Komentarz, red. Z. Ofiarski, Warszawa 2020.

Okoń M., Fundacje prawa prywatnego a fundacje prawa publicznego. Zagadnienie nadzoru nad ich działalnościa, ,Administracja. Teoria - Dydaktyka — Praktyka” 2011, nr 3.

Okoń M., Fundacje prawa publicznego w prawie polskim, „Kontrola Państwowa” 2012, nr 1.

Piechowiak M., Prawne a pozaprawne pojęcie dobra wspólnego, [w:] Dobro wspólne. Teoria i praktyka, red. W. Arndt, Warszawa 2013.

Prawo administracyjne. Część ogólna, ustrojowe prawo administracyjne, wybrane zagadnienia materialnego prawa administracyjnego, red. M. Zdyb, J. Stelmasiak, Warszawa 2020.

Przybysz P., Instytucje prawa administracyjnego, Warszawa 2020.

Reppé W.E., Encyklopedia nauk politycznych, t. 2, Warszawa 1937.

Reppé W.E., Fundacje, Warszawa 1937.

Sokolewicz W., Artykut 12, [w:] Konstytucja Rzeczpospolitej Polskiej. Komentarz, t. 5, red. L. Garlicki, Warszawa 2007.

Stahl M., Inne podmioty administrujace, [w:] System Prawa Administracyjnego, t. 6. Podmioty administrujące, red. R. Hauser, Z. Niewiadomski, A. Wróbel, Warszawa 2011.

Stasikowski R., Pluralizm administracji publicznej, Warszawa 2019.

Szlachetko K., Fundacje Samorządowe, [w:] Podmiotowość samorządu terytorialnego a zakres jego zadań i kompetencji, red. K. Małysa-Sulińska, M. Stec, Warszawa 2020.

Wilczyński P., Podmioty niepubliczne w sferze administracji publicznej, „Państwo i Prawo” 2002, nr 2.

Żukowski P.M., Tadeusz Antoni Bigo (1894-1975). Droga na katedrę uniwersytecka we Wrocławiu, „Folia Iuridica Universitatis Wratislaviensis” 2015, nr 4.

Prawo 333, 2021

(C) for this edition by CNS 


\section{Foundations of Public Law in the Light of Tadeusz Bigo's Academic Achievements}

Summary

The aim of the article is to characterize the notion of a public-law foundation against the background of Tadeusz Bigo's reflection on public-legal relations. There should be emphasized the importance of work of Professor Tadeusz Bigo for the current doctrine of administrative law. Examples of contemporary foundations of public law illustrate the considerations undertaken in the article. The content of the article is divided into three chapters, introduction, and conclusion. In the research, a theoretical-legal method and a dogmatic-legal method were used. The research shows that there is a theoretical possibility to include public-law-foundations in the category of public-legal-associations, although such categorization encounters difficulties related to the factual substrate of foundations.

Keywords: foundation, foundation of public law, Tadeusz Bigo, public-legal association. 